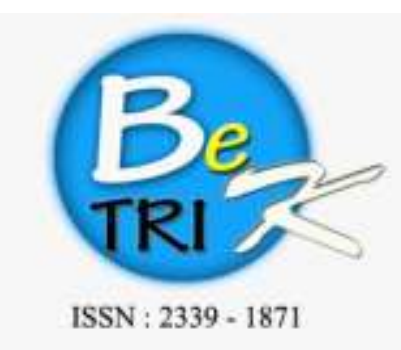

JURNAL ILMIAH BETRIK

Editor Office : LPPM Sekolah Tinggi Teknologi Pagar Alam, Jn. Masik Siagim No. 75 Simpang Mbacang, Pagar Alam, SUM-SEL, Indonesia Phone : +62 852-7901-1390.

Email : betrik@lppmsttpagaralam.ac.id |admin.jurnal@lppmsttpagaralam.ac.id Website : hrtps://ejournal.lppmsttpagaralam.ac.id/index.php/betrik/index

\title{
PENERAPAN E-COMMERCE PADA TOKO MAWAR SONGKET PALEMBANG BERBASIS WEB
}

\author{
Dinny Komalasari ${ }^{1}$, Iin Seprina $^{2}$ \\ ${ }^{1}$ Program studi Komputerisasi Akuntansi, ${ }^{2}$ Program Studi Sistem Informasi \\ Universitas Bina Darma Palembang \\ E-mail : ${ }^{1}$ dinny.komalasari@binadarma.ac.id, $\underline{\text { iin_Seprina@binadarma.ac.id }}$
}

\begin{abstract}
Abstrak : Dalam suatu lembaga atau unit kerja yang melayani kebutuhan publik baik internal maupun eksternal sangat diperlukan informasi dan pengelolaan yang tepat dan akurat dalam aktifitas lembaga atau unit kerja tersebut. Dengan sistem informasi dan system operasional yang sesuai kebutuhan, maka aktivitas dalam lembaga atau unit kerja tersebut dapat dilaksanakan dengan efisien dan efektif. Penelitian dilakukan secara langsung dengan melakukan observasi dengan pemilik Toko Mawar Songket dan mengamati proses transaksi penjualan, pembelian. Sonket. Program ini dibuat dengan aplikais Macromedia MX 2004 dengan bahasa program PHP dan MySQL sebagai databaseya. Dapat disimpulkan bahwa aplikasi penjualan Songket. Melina ini telah didesain dan bertujuan untuk memudahkan pembeli dalam memilih barang, dan manageman untuk melakukan transaksi penjualan maupun pembelian barang berupa songket, baju, kain, dan aksesoris, dan terutama bias meningkatkan omset penjualan pada Toko Mawar Songket Palembang
\end{abstract}

Kata Kunci : E-Commerce, $M y S q l, P H P$

Abstract: In an institution or work unit that serves the needs of both internal and external public is necessary information and proper and accurate management in the activities of the institution or work unit. With the information system and operational system as needed, then the activities within the institution or work unit can be implemented efficiently and effectively. The study was conducted directly by observing with the owner of Songket Rose Store and observing the process of sales transaction, purchase. Sonket. This program was created with aplikais Macromedia MX 2004 with the program language PHP and MySQL as databaseya. It can be concluded that the Songket sales app. Melina has been designed and aims to facilitate buyers in choosing goods, and manageman to conduct sales transactions and purchase of goods in the form of songket, clothes, cloth, and accessories, and especially bias increase sales turnover at Toko Mawar Songket Palembang

Keywords: E-Commerce, MySql, PHP

\section{PENDAhUluAN}

Tradisi Indonesia yang sangat beragam diantaranya adalah tradisi tenun, hasil dari tenunan yang sangat terkenal adalah tenuna kain songket. Songket keemasan dikaitkan dengankegemilangan Sriwijaya, kemaharajaa $\mathrm{n}$ niaga maritim nan makmur lagi kaya yang bersemi pada abad ke-7 hingga ke-13 di 
Sumatera. Hal ini dikarenakan kenyataan bahwa pusat kerajinan songket paling terkenal di Indonesia adalah kota Palembang. Songket adalah kain mewah yang aslinya memerlukan sejumlah emas asli untuk dijadikan benang emas, kemudian ditenun tangan menjadi kain yang cantik. Secara sejarah tambang emas di Sumatera terletak di Sumatera Selatan dan di pedalaman dataran tinggi Minangkabau. Meskipun benang emas ditemukan di reruntuhan situs Sriwijaya di Sumatera, bersama dengan batu mirah delima yang belum diasah, serta potongan lempeng emas, hingga kini belum ada bukti pasti bahwa penenun lokal telah menggunakan benang emas seawal tahun 600-an hingga 700-an masehi. Songket Palembang merupakan songket terbaik di Indonesia baik diukur dari segi kualitasnya yang dijuluki "Ratu Segala Kain". Songket eksklusif memerlukan waktu dua sampai tiga bulan untuk menyelesaikannya, sedangkan songket biasa hanya memerlukan waktu sekitar 3 hari.

Dalam industri yang melayani kebutuhan masyarakat baik internal maupun eksternal diperlukan informasi dan pengolahan yang tepat dan akurat. Dengan sistem informasi dan sistem operasional yang sesuai kebutuhan, maka aktivitas kerja tersebut dapat dilaksanakan dengan efisien dan efektif.

Dalam pengolahan data transaksi barang dan persedian stok barang di Toko
Mawar Songket Palembang masih menggunakan pembukuan atau masih manual, dimana dari hasil pendataan data tersebut masih kurang efisien.

Dari permasalahan di atas, perlu adanya sistem untuk membantu dalam mendata jumlah stok ketersediaan barang, transaksi pembelian dan laporan transaksi. Untuk itulah penulis mengangkat permasalahan ini dengan judul "Penerapan E-Commerce pada toko songket Palembang Berbasis Web".

\section{METODOLOGI PENELITIAN}

\subsection{E-Commerce}

Menurut David Baum (2000), Merupakan satu set dinamis teknologi, aplikasi, dan proses bisnis yang menghubungkan perusahaan, konsumen, dan komunitas tertentu melalui transaksi elektronik dan perdagangan barang, pelavanan, dan informasi yang dilakukan secara elektronik.

E-commerce adalah kegiatan-kegiatan bisnis yang menyangkut konsumen (consumers), manufaktur (manufactures), ser vice providers dan pedagang perantara (intermediaries) dengan menggunakan jaringan-jaringan komputer (komputer networks) yaitu internet.

Definisi dari e-commerce menurut Kalakota dan Whinston (1997) dapat ditinjau dalam 3 perspektif berikut: 
1. Perspektif komunikasi, e-commerce adalah pengiriman barang, layanan, informasi, atau pembayaran melalui jaringan komputer atau melalui peralatan elektronik lainnya.

2. Perspektif proses bisnis, e-commerce adalah aplikasi dari teknologi yang menuju otomatisasi dari transaksi bisnis dan aliran kerja.

3. Perspektif layanan, e-commerce merupakan suatu alat yang memenuhi keinginan perusahaan, konsumen, dan manajemen untuk memangkas biaya layanan (service cost) ketika meningkatkan kualitas barang dan meningkatkan kecepatan layanan pengiriman.

\subsection{Analisis Sistem}

\subsubsection{Use Case Diagram}

Use case atau diagram use case menangkap interaksi yang terjadi antara penghasil informasi (producer) dan pengguna informasi (consumer), dan juga bagaimana terjadi interajsi dengan system/perangkat itu sendiri (Roger S.Pressman, Ph.D. 2012:188). Use case digunakan untuk mengetahui fungsi apa saja yang ada didalam sebuah sistem informasi dan siapa saja yang berhak menggunakan fungsi-fungsi itu.
Tabel 1. Simbol-simbol Diagram Uses Case

\begin{tabular}{llr}
\hline \multicolumn{1}{c}{ Simbol } & \multicolumn{2}{c}{ Deskripsi } \\
\hline Use Case & $\begin{array}{l}\text { Fungsionalitas yang } \\
\text { disediakan } \\
\text { sebagai unit-unit } \\
\text { saling bertukar } \begin{array}{r}\text { yang } \\
\text { pesan } \\
\text { antar unit atau aktor. }\end{array}\end{array}$ \\
\hline Aktor/actor & $\begin{array}{l}\text { orang, proses atau } \\
\text { sistem lain yang } \\
\text { beerinteraksi } \\
\text { sistem informasi yanng } \\
\text { akan dibuat. }\end{array}$ \\
\hline & &
\end{tabular}

\begin{tabular}{ll}
\hline Asosiasi/asociation & $\begin{array}{l}\text { Komunikasi antara aktor } \\
\text { dan use case yang } \\
\text { berpartisipasi pada use } \\
\text { case atau use case } \\
\text { memiliki interaksi } \\
\text { dengan aktor. }\end{array}$ \\
\hline $\begin{array}{l}\text { Generalisasi/genera } \\
\text { lization }\end{array}$ & $\begin{array}{l}\text { Hubungan generalisasi } \\
\text { dan spesialisasi (umum } \\
\text { dan khusus) antara dua }\end{array}$ \\
& $\begin{array}{l}\text { buah use case dimana } \\
\text { fungsi yang satu adalah } \\
\text { fungsi yang lebih umum } \\
\text { dari lainnya. }\end{array}$
\end{tabular}

\subsubsection{Activity Diagram}

Diagram Aktivitas menggunakan sebuah kota yang bersisi lengkung untuk menggambarkan fungsi tertentu yang ada dalam suatu system/perangkat lunak yang akan dikembangkan ( Roger S.Pressman, Ph.D. 2012:195)

Berikut adalah simbol-simbol yang ada pada diagram aktivitas:

Tabel 2.

\section{Simbol-simbol Activity Diagram}

\begin{tabular}{llr}
\hline \multicolumn{1}{c}{ Simbol } & \multicolumn{2}{c}{ Deskripsi } \\
\hline Status awal & $\begin{array}{l}\text { Status } \\
\text { aktivitas } \\
\text { sebuah }\end{array}$ & $\begin{array}{r}\text { awal } \\
\text { diagram }\end{array}$ \\
\hline
\end{tabular}




\begin{tabular}{|c|c|}
\hline & $\begin{array}{l}\text { aktivitas } \\
\text { memiliki sebuah } \\
\text { status awal. }\end{array}$ \\
\hline Aktivitas & $\begin{array}{l}\text { Aktivitas yang } \\
\text { dilakukan sistem, } \\
\text { aktivitas biasanya } \\
\text { diawali dengan } \\
\text { kata kerja. }\end{array}$ \\
\hline Percabangan/decision & $\begin{array}{l}\text { Asosiasi } \\
\text { percabangan } \\
\text { dimana jika ada } \\
\text { pilihan aktivitas } \\
\text { lebih dari satu. }\end{array}$ \\
\hline Penggabungan/join & \begin{tabular}{l}
\multicolumn{3}{l}{ Asosiasi } \\
penggabungan \\
dimana lebih \\
dari $\quad$ satu \\
aktivitas \\
digabungkan \\
menjadi satu.
\end{tabular} \\
\hline Status akhir & $\begin{array}{lr}\text { Status } & \text { akhir } \\
\text { yang dilakukan } \\
\text { sistem, sebuah } \\
\text { diagram aktivitas } \\
\text { memiliki sebuah } \\
\text { status akhir. }\end{array}$ \\
\hline
\end{tabular}

\subsection{Metode Pengembangan Sistem}

Metode yang digunakan dalam penelitian ini adalah menggunakan metode waterfall . metode ini memilki tahapan atau langkah-langkah sebagai berikut Survei Sistem, Analisa Sistem, Design Sistem, Pembuatan Sistem, Implementasi Sistem, Pemeliharaan Sistem.

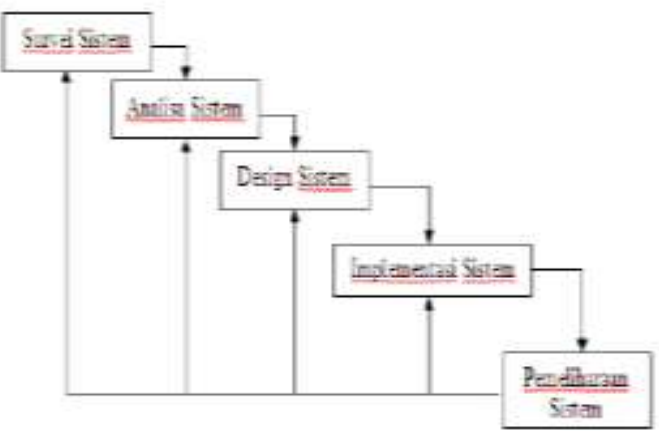

Gambar 1. Waterfall

\section{a. Survei sistem}

Pada Tahap ini untuk menentukan problem-problem atau kebutuhan yang timbul. Pengembangan sistem secara menyeluruh diperlukan dan untuk pemecahannya dilakukan usaha yang lain. Salah satu alternatifnya dengan tidak merubah sistem yang ada. Alternatif lainnya adalah mungkin hanya diperlukan alternatif lainnya mungkin hanya diperlukan perbaikanperbaikan saja pada sistem tanpa harus menggantinya.

\section{b. Analisis Sistem}

Pada tahap ini bertitik-tolak pada kegiatan-kegiatan dan tugas-tugas dimana sistem yang berjalan dipelajari secara lebih mendalam, konsepsi dan usulan dibuat untuk menjadi landasan bagi sistem yang baru yang akan dibangun.Akhir tahap ini merupakan separuh kegiatan dari usaha pengembangan sistem informasi yang telah diselesaikan. Salah satu tujuan terpenting pada tahap ini adalah untuk mendefinisikan sistem berjalan. Pemakai sistem dan analisa sistem bekerjasama 
untuk menjabarkan kebutuhan dan kemampuan dari sistem baru yang akan diusulkan.

\section{c. Desain Sistem}

Pada tahap ini, spesifikasi perangkat keras dan perangkat lunak (HW/SW) yang telah disusun pada tahap sebelumnya ditinjau kembali beserta programnya. Para pemakai sistem pun mulai diberi pelatihan. Dan dilakukan tes sistem secara menyeluruh. Apabila hasil pengetesan yang dilakukan steering committee telah selesai, maka persetujuannya untuk tahap selanjutnya.

\section{d. Implementasi Sistem}

Tahap ini adalah prosedur yang dilakukan untuk menyelesaikan desain sistem yang ada dalam dokumen disain sistem yang disetujui dalam hal menguji, menginstall dan memulai penggunaan sistem baru atau

sistem yang telah diperbaiki. Tujuan dari tahap implementasi ini adalah untuk menyelesaikan disain sistem yang telah disetujui,dalam hal menguji serta mendokumentasikan programprogram dan prosedur sistem yang diperlukan, memastikan personil yang terlibat dapat mengoperasikan sistem baru dan memastikan bahwa konversi sistem lama ke sistem yang baru dapat berjalan secara baik dan benar.

\section{e. Pemeliharaan Sistem}

Pada tahap ini, disarankan adanya dua tahap review yang harus dilaksanakan. Tahap pertama kali tidak terlalu lama setelah penerapan sistem, di mana tim proyek masih belum terlalu lama dalam mengerjakannya. Review berikutnya dapat dilaksanakan kirakira setelah enam bulan berjalan. Tujuannya adalah untuk menyakinkan apakah sistem tersebut berjalan sesuai dengan tujuan semula dan apakah masih ada perbaikan atau penyempurnaan yang harus dilakukan. Selain itu, tahap ini juga merupakan bentuk evaluasi untuk memantau agar sistem informasi yang dioperasikan dapat berjalan optimal dan sesuai dengan harapan pemakai maupun organisasi yang menggunakan sistem tersebut. Selanjutnya setiap tahun, organisasi tersebut menggunakan $10 \%$ - $25 \%$ dari biaya sistem awal untuk pemeiharaan sistem tersebut. Tujuan dari pemeliharaan sistem ini adalah untuk melakukan evaluasi terhadap sistem secara cepat dan efisien, serta dapat menyempurnakan proses pemeliharaan sistem yang selalu menganalisis kebutuhan informasi yang dihasilkan sistem tersebut dan meminimalkan gangguan serta kontrol gangguan operasi yang disebabkan oleh proses pemeliharaan sistem.

\section{HASIL DAN PEMBAHASAN}

\subsection{Hasil}

Hasil akhir dari penelitian di Toko Mawar Songket Palembang, maka telah ditentukan penerapan sistem berbasis web yang di rancang dengan menggunakan aplikasi Macromedia MX 2004 dengan 
bahasa PHP dan MySql sebagai databasenya, dengan judul. "Penerapan ECommerce pada Toko Mawar Songket Palembang.

\subsection{Pembahasan}

Setelah memperoleh gambaran hasil penelitian sistem yang dihasilkan yaitu sebuah sistem berbasis web yang dapat digunakan untuk menjual barang pada Toko Mawar Songket Palembang. Dalam mengoperasikan sistem, pengguna harus mengikuti ketentuan-ketentuan yang ada pada sistem. Adapun pembahasannya adalah sebagai berikut :

\subsubsection{Halaman Login}

Halaman login ditampilkan sebelum membuka sistem, user diwajibkan login terlebih dahulu.

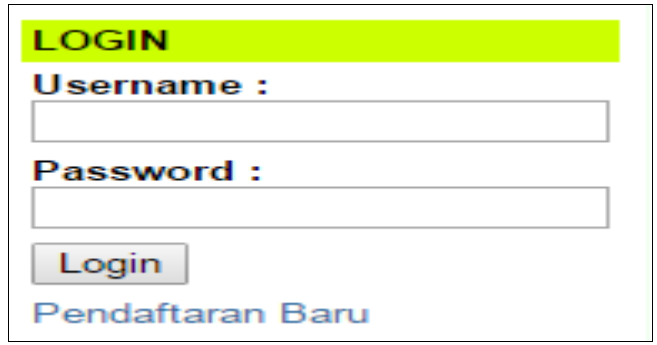

Gambar 2. Halaman Login

\subsubsection{Halaman Daftar Login}

Halaman ini untuk pelanggan apabila belum memiliki username dan password untuk login.

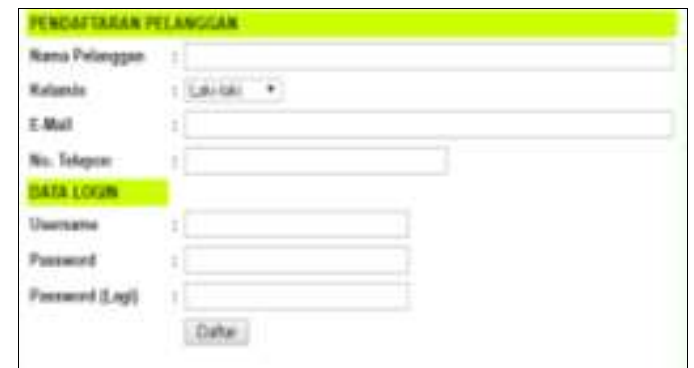

\section{Gambar 3. Halaman Daftar Login}

\subsubsection{Halaman Utama}

Halaman home ditampilkan setelah user berhasil melakukan login, yang terdiri dari banyak pilihan menu seperti menu, sejarah songket, songket, panduan, konfirmasi, keranjang belanja, tampilkan transaksi, kategori barang dan logout.

\subsubsection{Halaman kategori}

Halaman ini berfungi untuk memudahkan pelanggan untuk memilih barang yang sudah dalam kategori barang masingmasing.

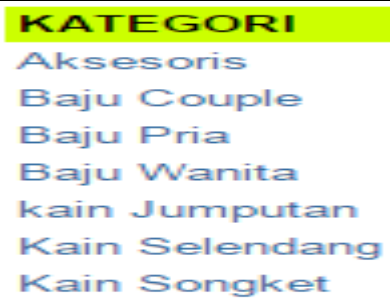

\section{Simpulan}

Berdasarkan penelitian yang telah penulis lakukan, maka dapat ditarik kesimpulan sebagai berikut:.

1. Sistem yang dihasilkan adalah Sistem penjualan songket di Toko Mawar Songket Palembang yang menggunakan bahasa PHP dan Mysql sebagai database nya. 
2. Dengan adanya sistem ini diharapkan dapat membantu mempermudah penjualan songket serta dapat meningkatkan omset pada Toko Mawar Songket Palembang

3. Sistem ini memudahkan owner dalam pengolahan data barang dan data transaksi.

\section{DAFTAR PUSTAKA}

A.S, Rosa. M. Shalahuddin, 2006. Rekayasa Perangkat Lubak, Bandung : INFORMATIKA

Arief. "Pengertian PHP". 2011.

http://tipsserbaserbi.blogspot.co.id/2016/0 2/pengertian-website-menurut-paraahli.html.

Baum, David "Pengertian E-Commerce". 2000. https://shygirlmiauw.wordpress.com/ecommerce-menurut-david-baum-2/

Lukmanul, Hakim. "Pengertian Website". 2014. http://www.tipsserbaserbi.blogspot.co.id/ 2016/02/pengertian-website-menurutpara-ahli.html .

Pressman, Roger S, PH.D., 2012. Rekayasa Perangkat Lunak, Bandung : INFORMATIKA

Raharjo, Budi. (1985)."pengeritan entity relationship diagram", dalam Sibero, 2011. Membuat databse dengan mengguankan MyAql Bandung : Informatika.

Raharjo, Budi. 2011. Belajar otodidak membuat database, Bandung : INFORMATIKA.

Ramdhani"Pengertian Internet”. 2013. http://www.seputarpendidikan.com/2016/ 02/9-pengertian-jaringan-internetmenurut-para-ahli.html . 